\title{
Supply chain value creation methodology under BSC approach
}

\author{
Seyedehfatemeh Golrizgashti
}

Received: 13 April 2013/Accepted: 24 May 2014/Published online: 14 June 2014

(C) The Author(s) 2014. This article is published with open access at Springerlink.com

\begin{abstract}
The objective of this paper is proposing a developed balanced scorecard approach to measure supply chain performance with the aim of creating more value in manufacturing and business operations. The most important metrics have been selected based on experts' opinion acquired by in-depth interviews focused on creating more value for stakeholders. Using factor analysis method, a survey research has been used to categorize selected metrics into balanced scorecard perspectives. The result identifies the intensity of correlation between perspectives and cause-and-effect chains among them using statistical method based on a real case study in home appliance manufacturing industries.
\end{abstract}

Keywords Supply chain - Balanced scored - Performance measurement $\cdot$ Stakeholders $\cdot$ Value

\section{Introduction}

Successful engineering managers require experience in business and engineering by applying engineering principles to business practice. Engineering managers usually focused on production process to improve product quality and to decrease cost of production. They monitor many metrics to evaluate process during supply chain without focusing on value creation for supply chain stakeholders. Balanced scorecard (BSC) is an effective approach that managers use to evaluate supply chain performance.

S. Golrizgashti $(\bowtie)$

Department of Industrial Engineering, South Tehran Branch, Islamic Azad University, Tehran, Iran

e-mail: Sf_golrizgashti@Azad.ac.ir
There are many researches about applying BSC approach in the literature, but there is no research focusing on using this approach to create more value during supply chain in competitive market. Identifying key value metrics and defining their effects on other metrics can help engineering managers to improve the most important metrics instead of monitoring all of them. In this paper, correlation between BSC perspectives and cause-and-effect chains among them has been identified. Therefore, this paper considers how production and operations management can respond to the pressures of the competitive global marketplace by focusing more on value metrics in the supply chain. Applying proposed framework in this research by engineering mangers causes adding flexibility to the system, reducing production cost and increasing stakeholder's satisfaction via creating more value in supply chain.

Supply chain, emerging in the 1980s, is an internationally used term that encompasses every effort engaged in production and delivering of final products and services, from the suppliers' suppliers to the customers' customers (Khalifa 2004). Supply chain management is a strategic implication for any business activity and any company. Performance measurement is essential and should be a main part of any business strategy (Bhagwat and Sharma 2007). Therefore, the effective collaboration of partners and coordination of all activities within the supply chain are prerequisites in competitive and dynamic market conditions (Bahri and Tarokh 2012). Shepherd and Günter (2006) mentioned that performance measurement is a critical issue to improve supply chains' effectiveness and efficiency of companies (Beamon 1999; Shepherd and Günter 2006). According to Beamon (1999) and Gunasekaran et al. (2004) decision makers in supply chains should focus on developing measurement metrics for evaluating the performance. Many methods have been 
suggested for evaluation of SCM in organizations. Traditional methods in their literature focus only on well-known financial measures. These methods are not necessarily suitable for evaluating supply chain performance in today's market. Due to the fierce competition among supply chains in today's market, creating more value in supply chain determines competitive advantage of a firm over its competitors. Newer generations of supply chains have to provide tangible and intangible benefits for their stakeholders. Therefore, it is an appropriate idea to use a balanced approach to measure and evaluate supply chain performance comprehensively. According to the past literatures, there is a lack of effective performance metrics and their integration at strategic, tactical, and operational levels (Gunasekaran et al. 2001; Hudson et al. 2001). According to Taghizadeh and Hafezi (2012), determining the quantitative criteria and parameters through which the most suitable partner could be chosen seems to be useful.

There are many metrics suggested in several literatures to evaluate supply chain performance. These metrics focused mostly on financial benefits and customer satisfaction criteria. Some of these metrics have been repeated in different perspectives of performance measurement without identifying vital correlations. Hence, there is a lack of enough attention to other supply chain stakeholders, improving value creation and, defining correlation between metrics and performance measuring perspectives. Having an overview on most of theoretical and empirical studies which focused on BSC approach for improving SCM performance measurement, a new balanced SCM scorecard has been developed in this study to evaluate SCM performance with respect to all its dimensions. A balanced performance measurement of SCM helps organizations to improve their internal and external functions of business and create more value for their stakeholders. The proposed developed BSC approach is the result of investigating more than 300 existing metrics in several literatures and having them confirmed using factor analysis method considering their highest correlation with each of BSC perspectives.

\section{Literature review}

Supply chain management and value creation

According to Chopra and Meindl (2001), the objective of supply chain is to maximize the overall value generated. The value a supply chain generates is the difference between what the final product is worth and the customer's request, and according to Satapathy and Mishra (2013) the customer is satisfied when he/she feels that the service performance fits well with his/her personal framework (confirming). If it remains below expectations, then the customer will be dissatisfied (disconfirming). In most commercial supply chains, value is correlated with profitability. Estampe et al. (2010) state that supply chain management creates value for companies, customers and stakeholders who are interacting along the supply chain. Bhagwat and Sharma (2007) mentioned that companies can continue to improve and create value in their supply chain by applying balanced scorecard approach and continuous evaluation.

Due to the fierce competition among supply chains in today's market, creating more value via improving supply chain performance determines competitive advantage for a firm over its competitors. Hence, evaluating supply chain performance with focus on creation of more value is an essential issue in supply chain management. Some authors mentioned that companies can use balanced scorecard approach, including customer, financial, internal business and, learning and innovation perspectives, to evaluate supply chain performance and to consequently obtain value-adding products and services (Martinsons et al. 1999). Components of BSC approach can help companies to create more value to their stakeholders. For an instance, customer perspective is external clients and affects on society. Internal business perspective consists of processes, which enable the organization to create value for its customer and to reach its financial goals (Hongxia and Zhipeng 2007). The proposed framework develops BSC approach with focus on effective metrics to evaluate supply chain performance comprehensively for gaining more value.

The balanced scorecard

There are different methods to evaluate supply chain performance (Bititici et al. 2005; Chan and Qi 2003a, b; Chan and Chan 2006; Sharma et al. 2005). Some researchers have used BSC and Activity Based Costing (ABC) methods for such evaluation (Liberatore and Miller 1998). The balanced frameworks such as performance measurement metrics, results-determinants framework, performance pyramid, etc., have been proposed by some other researchers on the other hand (Neely 2005).

The Supply Chain Operations Reference (SCOR) model has been developed as a systematic supply chain performance measurement to improve supply chain construction by identifying, evaluating and monitoring supply chain performance (Lockamy and McCormack 2004). In this paper, BSC approach is used to propose a developed framework to help companies to create more value for their customers, employees and shareholders as stakeholders of supply chain. According to Bititici et al. (2005), performance measurement systems are needed at different 
levels of decision making in the industry or service contexts.

The BSC approach has been proposed by Kaplan and Norton (1992) as a tool to evaluate corporate performance from four different perspectives: the financial, the internal business process, the customer, and the learning and growth. They have suggested the hypothesis that some relationships exist among the metrics of the evaluation system. They expressed that there is cause-and-effect relation between the perspectives of the BSC. Some studies have tried to prove the existence of the cause-and-effect chain among different perspectives of BSC (Wang et al. 2010). The BSC approach helps managers to evaluate financial measures of past performance with their measures of the drivers of future performance (Bhagwat and Sharma 2007).

BSC have been used for many areas. According to Youngblood Alisha and Terry (2003), balanced scorecard provides valuable feedback on a variety of performance metrics. They introduced BSC as a better way to evaluate investment alternatives. BSC approach creates a balance between short-term and long-term objectives, between financial and non-financial measures, between lagging and leading indicators, and between internal and external performance perspectives. Malmi (2001) mentioned that the BSC can be applied as a control panel, pedals and steering wheel. Martinsons et al. (1999) believed that many companies apply BSC as the foundation for their strategic management system. Some managers have used it to align their businesses to new strategies, aiming to move away from cost reduction and shift toward growth opportunities based on more customized, value-adding products and services. Many methods of performance measurement have been reported in the past literatures, but in this paper we presented a developed BSC approach based on the BSC framework proposed by Kaplan and Norton (Table 1).

Table 1 The four perspectives in a balanced scorecard (Kaplan and Norton 1992)

\begin{tabular}{|c|c|}
\hline $\begin{array}{l}\text { Customer perspective (value- } \\
\text { adding view) }\end{array}$ & $\begin{array}{l}\text { Financial perspective } \\
\text { (shareholders' view) }\end{array}$ \\
\hline $\begin{array}{l}\text { Mission: to achieve our vision by } \\
\text { delivering value to our } \\
\text { customer }\end{array}$ & $\begin{array}{l}\text { Mission: to succeed financially, } \\
\text { by delivering value to our } \\
\text { shareholders }\end{array}$ \\
\hline $\begin{array}{l}\text { Internal perspective (process- } \\
\text { based view) }\end{array}$ & $\begin{array}{l}\text { Learning and growth perspective } \\
\text { (future view) }\end{array}$ \\
\hline $\begin{array}{l}\text { Mission: to promote efficiency } \\
\text { and effectiveness in our } \\
\text { business processes }\end{array}$ & $\begin{array}{l}\text { Mission: to achieve our vision, by } \\
\text { sustaining innovation and } \\
\text { change capabilities, through } \\
\text { continuous improvement and } \\
\text { preparation for future } \\
\text { challenges }\end{array}$ \\
\hline
\end{tabular}

Performance and measurement of supply chain

Performance measurement is the feedback or information on activities with respect to meeting customers' expectations and strategic objectives (Chan 2003). Butler Renee et al. (2006) mentioned that planning a supply chain for a new product requires analysis demand and cost uncertainty in market conditions over time. Therefore, an effective approach is essential to obtain customer demand during supply chain. Performance measurement can improve all areas in supply chain such as quality, price, delivery, and so on. In this paper, we offer some of the most appropriate performance metrics and measures for SCM with special focus on value creation. Most traditional methods focus on well-known financial measures, such as the return on investment (ROI), net present value (NPV), the internal rate of return (IRR), and the payback period. These methods could best suit to measure created value in simple SCM applications (Bhagwat and Sharma 2007). Evaluation methods and metrics that rely on financial measures are not proper enough for newer generation of SCM applications, which strive for more value. Therefore, there has not been any well-designed model to measure supply chain performance with strong focus on value creation.

It is needed to study the measures and metrics for evaluating supply chain performance comprehensively because there is lack of a balanced approach, which includes both financial and non-financial measures (Gunasekaran et al. 2001; Hudson et al. 2001). They also identified the problem of lack of enough knowledge for deciding on number of metrics to be used by firms for supply chain performance evaluation. Companies use a large number of performance metrics while they can use only a few suitable metrics. Finally, there is an important distinction between metrics at strategic, tactical, and operational levels. Each metric has to be classified into these three levels, where it would be most appropriate. Therefore, literatures on supply chain management lack a study proposing a framework as a comprehensive set of effective metrics for performance measurement. New generation of supply chains needs to be well investigated and evaluated by a wide range of tangible and intangible metrics to survive in competitive market.

\section{Balanced scorecard for supply chain evaluation}

The BSC for SCM framework presented in this study is structurally similar to the BSC framework at the corporate management level proposed by Kaplan and Norton. We have identified supply chain performance metrics from the past literature reviews, with focus on value creation in supply chain and hereby propose a framework for SCM performance evaluation. In this paper, the BSC is applied to these metrics with the intention of assessing SCM performance 
comprehensively. The four perspectives of the BSC are considered and these metrics are fitted into them as shown in exhibit 2 . The table indicates the high performance metrics that target broader functional areas of supply chain with respect to value creation. Bhagwat and Sharma (2007) mentioned that the perspectives should be reviewed periodically and updated as necessary. The measures included in the given BSC should be traced over time, and integrated explicitly into the strategic SCM process.

\section{Materials and methods}

\section{Developed balanced scorecard}

Investigating the proposed models, this study has endeavored to discover every possible metrics regarding evaluation of value creation process along supply chains. It should be noted that although all of the offered metrics within selected articles are suitable, they lack a holistic view of evaluating supply chain for value creation and comprehensive assessment. Thus, it is strived in this study to establish a technical review of supply chain performance metrics with focus on value creation for stakeholders. By the review of literature on SCM performance measures, more than 300 metrics were identified. These metrics are too many for managers to monitor supply chain performance. Measuring all these metrics is difficult and some of them may not have important affect on improving supply chain areas. Thus, it needed to develop an effective approach by effective metrics and align it to value metrics in supply chain.

\section{Research method and data}

In this article, the BSC approach is applied to performance metrics with the intention of evaluating SCM performance comprehensively. Different metrics have to been fitted into four different perspectives of BSC. Firstly, the qualitative indepth interview method was applied to select performance metrics. After selecting effective metrics, the factor analysis method was applied to confirm metrics. Qualitative in-depth interview is an exploratory research technique with the ability of giving well-grounded, rich descriptive explanations (Sage Gordon and Langmaid 1998; Arksey and Knight 1999). Indeed, these methods permit concepts and meanings to be explored with better understanding than questionnaires.

\section{Case study}

The balanced SCM scorecard has been recently implemented in Parstoushe holding. It contains ten Iranian home appliance industries that apply BSC approach to evaluate supply chain management. Five are medium-sized companies and five are small-scale enterprise. The biggest company is a leading assembly manufacturer and operates in a multi-plant environment. It has been established in 1968 and situated in a major industrial town of north. It was the first company to launch the production of home appliances in Iran. The number of employees in the firm is 350. Distribution to dealer network and developing big after-sale services networks are the two important activities applied by this company. Four other case companies are manufacturers of home appliances too. They are mediumscale companies with manpower of nearly 300 . The five other case companies are small scale with manpower of 100. The companies have applied some ISO certificates such as 9001 and 10002 to improve their performances.

The main purpose of this study is identifying the intensity of correlation between perspectives of BSC applying in these companies. The managers' experiences emphasis performance improving via applying balanced scorecard.

The case companies use four perspectives in their scorecards suggested by Kaplan and Norton (Kaplan and Norton 1992). Applying BSC has been cause that the companies use most important metrics. Balanced scorecard is applied at several levels in companies such as production, marketing, financial, top manager level and esc. Therefore, managers have good experiences to select important metrics. They mentioned that selected metrics in their companies were related to strategic, tactical, and operational levels.

There are targets for each metric to improve supply chain performance in case companies. All employees try to achieve identified targets. All financial and non-financial metrics are important for companies to improve their performance. Key information has been imported to companies via BSCs metrics. To evaluate metrics, data collected from several tools included portal and total software via production and sales process. Information availability levels have been defined for $\mathrm{CEO}$, managers and key employees in companies to collect data and observe reports to evaluate metrics in their areas and to analysis their results. Managers have used results to review current strategies and applied new strategies to improve performance. Applying BSC approach affects the performance positively such as decreasing lead time and decreasing cost order. Managers can evaluate customer satisfaction by monitoring metrics related to customer perspective via BSC approach. They believe that monitoring financial metrics included assets cost, return on investment, and total inventory cost is not enough to improve supply chain performance; therefore, they measure non-financial metrics, for example, range of product and services, capacity utilization, the delivery channel, vehicle scheduling and so on too. Managers mentioned that evaluating metrics via BSC approach affects the cost performance, customer service, lead time, ROI and so on in these companies. Therefore, selecting effective metrics is very important to applying BSC approach (Table 2). 
Table 2 Key performance metrics

\begin{tabular}{|c|c|c|}
\hline BSC perspective & Metrics (factors) & References \\
\hline \multirow[t]{22}{*}{ Financial } & Cash to cash cycle time & Bolstorff (2003), Camerinelli and Cantu (2006) \\
\hline & Financial benefits & $\begin{array}{l}\text { Stewart(1991), Beamon (1999), Kleijnen and Smits-Pefformance (2003) } \\
\text { and Hongxia and Zhipeng (2007) }\end{array}$ \\
\hline & Final net profit & Stewart (1991) and Gunasekaran et al. (2001) \\
\hline & Value of stock & Mondragon et al. (2011) \\
\hline & Sale rate new product sale ratio & Hongxia and Zhipeng (2007), Cai et al. (2009) and Yang (2008) \\
\hline & Reverse logistics costs & $\begin{array}{l}\text { Bolstorff (2003), Hongxia and Zhipeng (2007) and Mondragon et al. } \\
\text { (2011) }\end{array}$ \\
\hline & Logistics cost & Identified during interviews \\
\hline & Productivity on time & Hongxia and Zhipeng (2007) \\
\hline & Waste reduction & Stewart (1991) \\
\hline & Security costs & Hongxia and Zhipeng (2007) \\
\hline & Cost of manpower resources & Hongxia and Zhipeng (2007) \\
\hline & Purchase costs & Li et al. 2009) \\
\hline & Rate of return on investment & $\begin{array}{l}\text { Christopher (1992), Dobler and Burt (1996), Beamon (1999), } \\
\text { Gunasekaran et al. (2001) and Bhagwat and Sharma (2007) }\end{array}$ \\
\hline & Variations against budget & Gunasekaran et al. (2001) and Bhagwat and Sharma (2007) \\
\hline & Supplier cost saving initiatives & Gunasekaran et al. (2001) and Bhagwat and Sharma (2007) \\
\hline & Cost per operation hour & Gunasekaran et al. (2001) and Bhagwat and Sharma (2007) \\
\hline & Total inventory cost as: incoming stock level & Gunasekaran et al. (2001) and Bhagwat and Sharma (2007) \\
\hline & Total inventory cost as: work in progress & Gunasekaran et al. (2001) and Bhagwat and Sharma (2007) \\
\hline & Total inventory cost as: scrap value & Gunasekaran et al. (2001) and Bhagwat and Sharma (2007) \\
\hline & Total inventory cost as: finished goods in transit & Gunasekaran et al. (2001) and Bhagwat and Sharma (2007) \\
\hline & Cost reduction project & Identified during interviews \\
\hline & Information carrying cost & $\begin{array}{l}\text { Levy (1997), Lee and Billington (1992), Gunasekaran et al. (2001), } \\
\text { Bolstorff (2003) and Bhagwat and Sharma (2007) }\end{array}$ \\
\hline \multirow[t]{20}{*}{ Customer } & Customer query time & $\begin{array}{l}\text { Mason-Jones and Towill (1997), Gunasekaran et al. (2001) and Bhagwat } \\
\text { and Sharma (2007) }\end{array}$ \\
\hline & Level of customer perceived value of product & Gunasekaran et al. (2001) and Bhagwat and Sharma (2007) \\
\hline & Range of products and services & Gunasekaran et al. (2001) and Bhagwat and Sharma (2007) \\
\hline & Order lead time & $\begin{array}{l}\text { Gunasekaran et al. (2001), Bolstorff (2003) and Bhagwat and Sharma } \\
\text { (2007) }\end{array}$ \\
\hline & $\begin{array}{l}\text { Flexibility of service system to meet particular } \\
\text { customer needs }\end{array}$ & Gunasekaran et al. (2001) and Bhagwat and Sharma (2007) \\
\hline & Delivery lead time & $\begin{array}{l}\text { Rushton and Oxley (1991), Christopher (1992) Gunasekaran et al. (2001) } \\
\text { and Bhagwat and Sharma (2007) }\end{array}$ \\
\hline & Percentage of on-time deliveries & Beamon (1999) and Soni and Kodali (2010) \\
\hline & Effectiveness of delivery invoice methods & Gunasekaran et al. (2001) and Bhagwat and Sharma (2007) \\
\hline & Client retaining & Yang (2008) \\
\hline & Accuracy of forecasting techniques & $\begin{array}{l}\text { Gunasekaran et al. (2001), Bhagwat and Sharma (2007), Yilmaz and } \\
\text { Bititci (2006) and Mondragon et al. (2011) }\end{array}$ \\
\hline & Market share & Identified during interviews \\
\hline & Answer time of complaint & Hongxia and Zhipeng (2007) \\
\hline & After-sale service quality level & Hongxia and Zhipeng (2007) \\
\hline & Price & Donnet et al. (2009) and Soni and Kodali (2010) \\
\hline & Rate of credit & Hongxia and Zhipeng (2007) \\
\hline & Wasting degree of energy sourcing & Hongxia and Zhipeng (2007) \\
\hline & Number of distribution channels & Identified during interviews \\
\hline & Time required to produce new product & Soni and Kodali (2010) \\
\hline & Average units returned & Mondragon et al. (2011) \\
\hline & Environment protection efficiency & Yang (2008) \\
\hline
\end{tabular}


Table 2 continued

\begin{tabular}{|c|c|c|}
\hline BSC perspective & Metrics (factors) & References \\
\hline & Production flexibility & Cai et al. (2009) and Soni and Kodali (2010) \\
\hline & Delivery reliability & Gunasekaran et al. (2001) and Bhagwat and Sharma (2007) \\
\hline & Responsiveness to urgent deliveries & $\begin{array}{l}\text { Gunasekaran et al. (2001), Bhagwat and Sharma (2007) and Soni } \\
\text { and Kodali (2010) }\end{array}$ \\
\hline & $\begin{array}{l}\text { Effectiveness of distribution planning } \\
\text { schedule }\end{array}$ & Gunasekaran et al. (2001) and Bhagwat and Sharma (2007) \\
\hline & Quality of delivery documentation & Gunasekaran et al. (2001) and Bhagwat and Sharma (2007) \\
\hline & Driver reliability for performance & Gunasekaran et al. (2001) and Bhagwat and Sharma (2007) \\
\hline & Quality of delivered goods & $\begin{array}{l}\text { Donnet et al. (2009), Gunasekaran et al. (2001), Bhagwat and } \\
\text { Sharma (2007) and Soni and Kodali (2010) }\end{array}$ \\
\hline & Achievement of defect free deliveries & Gunasekaran et al. (2001), Bhagwat and Sharma (2007) \\
\hline \multirow[t]{19}{*}{ Internal business } & Buyer-supplier partnership level & $\begin{array}{l}\text { Toni et al. (1994), Gunasekaran et al. (2001) and Bhagwat and } \\
\text { Sharma (2007) }\end{array}$ \\
\hline & Information share & $\begin{array}{l}\text { Angerhofer and Angelides (2006) and Hongxia and Zhipeng } \\
\text { (2007) }\end{array}$ \\
\hline & Group participation & Yang (2008) \\
\hline & Expansion capability & Soni and Kodali (2010) \\
\hline & Planning and ERP execution systems & Yilmaz and Bititci (2006) \\
\hline & Supplier collaborative planning systems & Yilmaz and Bititci (2006) \\
\hline & Raw material and resource usage rate & Yang (2008) \\
\hline & Internal process efficiency & Kleijnen and Smits-Pefformance (2003) \\
\hline & $\begin{array}{l}\text { Percentage of wrong products during } \\
\text { production }\end{array}$ & Soni and Kodali (2010) \\
\hline & Supplier rejection rate & Gunasekaran et al. (2001) and Bhagwat and Sharma (2007) \\
\hline & Total supply chain cycle time & Gunasekaran et al. (2001) and Bhagwat and Sharma (2007) \\
\hline & Supplier lead time against industry norms & Gunasekaran et al. (2001) and Bhagwat and Sharma (2007) \\
\hline & Level of supplier's defect free deliveries & Gunasekaran et al. (2001) and Bhagwat and Sharma (2007) \\
\hline & Purchase order cycle time & Gunasekaran et al. (2001) and Bhagwat and Sharma (2007) \\
\hline & Planned process cycle time & Gunasekaran et al. (2001) and Bhagwat and Sharma (2007) \\
\hline & $\begin{array}{l}\text { Effectiveness of master production } \\
\text { schedule }\end{array}$ & Gunasekaran et al. (2001) and Bhagwat and Sharma (2007) \\
\hline & Capacity utilization & $\begin{array}{l}\text { Stewart (1995), Gunasekaran et al. (2001) and Bhagwat and } \\
\text { Sharma (2007) }\end{array}$ \\
\hline & Efficiency of purchase order cycle time & Gunasekaran et al. (2001) and Bhagwat and Sharma (2007) \\
\hline & Frequency of delivery & Gunasekaran et al. (2001) and Bhagwat and Sharma (2007) \\
\hline \multirow[t]{12}{*}{ Learning and innovation } & Learning abilities & Stewart (1991) \\
\hline & Innovation abilities & Stewart (1991) \\
\hline & Product recycle interest & Yang (2008) \\
\hline & Use of new technology & Soni and Kodali (2010) \\
\hline & $\begin{array}{l}\text { Supplier assistance in solving technical } \\
\text { problems }\end{array}$ & $\begin{array}{l}\text { Soni and Kodali (2010), Gunasekaran et al. (2001) and Bhagwat } \\
\text { and Sharma (2007) }\end{array}$ \\
\hline & $\begin{array}{l}\text { Supplier ability to respond to quality } \\
\text { problems }\end{array}$ & Gunasekaran et al. (2001) and Bhagwat and Sharma (2007) \\
\hline & Supplier's booking in procedures & Gunasekaran et al. (2001) and Bhagwat and Sharma (2007) \\
\hline & Order entry methods & Gunasekaran et al. (2001) and Bhagwat and Sharma (2007) \\
\hline & Social programs investments & Identified during interviews \\
\hline & Employee turnover & Identified during interviews \\
\hline & Motivation plan & Identified during interviews \\
\hline & Employee training program & Identified during interviews \\
\hline
\end{tabular}


The main purpose of interviews and the key question was to find out the effective metrics to evaluate supply chain performance in case companies. Eighty-one metrics were resulted from interviews (shown in Table 2). As mention during interviews, some managers believed that it is needed to add some new metrics to their scorecards, to create more value for stakeholders. Hence, some new metrics were added according to experts' ideas mentioned in Table 2. In practice, most of the metrics correlate with each other and have tangled cause-and-effect interplays and can be fitted into more than one perspective (Norrekilt 2000). But some metrics have higher correlations with each other and with BSC perspectives. As an example, higher level of customer expectations (customer perspective) will lead companies to use new technology (learning and growth perspective) and this in turn will increase the market share and profitability (financial perspective) (Bhagwat and Sharma 2007). In most studies, performance metrics are classified into four perspectives and directly in quantitative terms. Therefore, metrics with high correlations with each other and BSC perspectives have to be identified and classified into four BSC categories. In this study, a statistical method is applied to identify high correlation between metrics and BSC perspectives.

Confirmatory factor analysis has been employed to confirm suitability of the metrics in the designed framework. Using factor analysis to generate the correlation metrics, the variables are collected in clusters so that the variables in the same cluster are more correlated than the variables belonging to different clusters (De Vaus 2002).

In order to empirically confirm the correlation between metrics and BSC perspectives, a questionnaire was developed and a survey was conducted. The sample is ten Iranian home appliance industrial, which has implemented BSC approach to evaluate their supply chain performance. The respondents are mainly experts or core members in the management team who have good understanding of the company's performance. The structured questionnaire consists of two sections: section A elicits general information, which includes name of their companies, age, current position, education and number of years they have been in service; Section B included assessments of balanced scorecard metrics in their companies. Respondents were asked to indicate their assessments of the company's current performance. Five-point Likert scale that ranged from " 1 = strongly bad" to "5 = strongly good" was used.

While the respondents of questionnaire were selected by simple random sampling, 30 copies of questionnaire were given out to experts in a pilot test. After revising or removing unsuitable items as per exerts' advice, author sent out 320 copies of questionnaire and received 301 validly completed copies for a $94 \%$ response rate. After collecting data from questionnaires, confirmatory analysis was run to confirm the relationship between metrics and BSC perspectives. Kaiser-Meyer-Olkin measure of sampling adequacy for this study is 0.717 , which proves the existing correlation is appropriate for factor analysis (Table 3).

Since the KMO value is in the acceptable range, the second phase can be started. Principal component analysis has been employed to extract the factors, and Varimax rotation has been used to clean up these factors in this study Table 4.

\section{Result}

The result of descriptive statistics is specified in Table 4. Every single metrics is fitted into the BSC perspective, which has higher correlations with the metrics. The values of skewness and kurtosis for all metrics are in the acceptable range.

The result of principal component analysis that has been employed to confirm the factors and Varimax rotation that has been used to clean up the factors is shown in Table 4. The correlation analysis indicates a strong positive association between metrics and the four BSC perspectives. To identify correlation between four BSC perspectives, a correlation test has been applied. The result of the test is presented in the Table 5 .

According to the literature, there is a cause-and-effect relation between the perspectives of BSC approach. In this study, the relationship has been confirmed using a statistical method based on a real case study. The correlation between four perspectives of BSC can be different in different industries. According to the results, all perspectives have acceptable correlation to each other with different amounts. The customer perspective has strong relation with other perspectives. For instance, in the Iranian home appliance industries, customer and financial perspectives have the highest correlation with each other. Thus, improving a perspective of supply chain performance affects the other perspectives positively. Managers can improve their supply chain performance by applying this proposed framework as a balanced way. Automation of data collection, electronic processing of information and improvement in reporting techniques can help companies to evaluate supply chain performance continuously (Fig. 1).

The value of correlation between all perspectives is in the interval $0.743-0.791$, which indicates a strong positive correlation. Therefore, all perspectives have strong correlation with each others. The value of correlation between 
Table 3 KMO statistic and Bartlett's test

\begin{tabular}{lll}
\hline Kaiser-Meyer-Olkin measure of sampling adequacy & 0.717 \\
Bartlett's test of sphericity & Approx. Chi square & 78.125 \\
& $d f$ & 10 \\
Sig. & 0.000
\end{tabular}

customer and financial perspectives is high. It shows that higher level of customer satisfaction and expectations will lead companies to more market share and will increase the profitability. Bhagwat and Sharma (2007) mentioned this result in their research too.

The value of correlations between business and financial perspective is more than others. It shows that the business process has the greatest impact on financial metrics and vice versa. When the business metrics, for example, purchase order cycle time and level of supplier's defect decrease, it strongly affect on cost reduction in financial perspective. Therefore, improving internal business metrics affects financial metrics strongly. According to the result, the value of correlation between all perspectives shows strong cause-and-effect relationships. Therefore, managers can improve their supply chain performance by monitoring metrics respect to four essential BSC perspectives. The value of correlations had been calculated according to the expert's opinion with respect to their firm's performance via a survey in selected case companies that apply BSC approach. The result is a validation on past researches.

Table 4 Explorative factor analysis on BSC

\begin{tabular}{|c|c|c|c|c|c|c|c|}
\hline Measurement items & Factor 1 & Factor 2 & Factor 3 & Factor 4 & $\begin{array}{l}\text { Eigen } \\
\text { value }\end{array}$ & $\begin{array}{l}\text { Cum. \% variance } \\
\text { explained }\end{array}$ & $\begin{array}{l}\text { Cronbach's } \\
\text { alpha }\end{array}$ \\
\hline F1: Cash to cash cycle time & 0.833 & & & & 22.719 & 28.048 & 0.974 \\
\hline F2: Financial benefits & 0.969 & & & & & & \\
\hline F3: Final net profit & 0.961 & & & & & & \\
\hline F4: Value of stock & 0.754 & & & & & & \\
\hline F5: Sale rate new product sale ratio & 0.743 & & & & & & \\
\hline F6: Reverse logistics costs & 0.859 & & & & & & \\
\hline F7: Logistics cost & 0.691 & & & & & & \\
\hline F8: Productivity on time & 0.833 & & & & & & \\
\hline F9: Waste reduction & 0.610 & & & & & & \\
\hline F10: Security costs & 0.862 & & & & & & \\
\hline F11: Cost of manpower resources & 0.964 & & & & & & \\
\hline F12: Purchase costs & 0.848 & & & & & & \\
\hline F13: Rate of return on investment & 0.967 & & & & & & \\
\hline F14: Variations against budget & 0.965 & & & & & & \\
\hline F15: Supplier cost saving initiatives & 0.698 & & & & & & \\
\hline F16: Cost per operation hour & 0.967 & & & & & & \\
\hline F17: Total inventory cost as: Incoming stock level & 0.951 & & & & & & \\
\hline F18: Total inventory cost as: work in progress & 0.947 & & & & & & \\
\hline F19: Total inventory cost as: Scrap value & 0.835 & & & & & & \\
\hline F20: Total inventory cost as: finished goods in transit & 0.874 & & & & & & \\
\hline F21: Cost reduction project & 0.694 & & & & & & \\
\hline F22: Information carrying cost & 0.848 & & & & & & \\
\hline L1: Learning abilities & & 0.806 & & & 21.760 & 54.912 & 0.839 \\
\hline L2: Innovation abilities & & 0.977 & & & & & \\
\hline L3: Product recycle interest & & 0.964 & & & & & \\
\hline L4: Use of new technology & & 0.958 & & & & & \\
\hline L5: Supplier assistance in solving technical problems & & 0.971 & & & & & \\
\hline L6: Supplier ability to respond to quality problems & & 0.968 & & & & & \\
\hline L7: Supplier's booking in procedures & & 0.970 & & & & & \\
\hline L8: Order entry methods & & 0.975 & & & & & \\
\hline L9: Social programs investments & & 0.968 & & & & & \\
\hline L10: Employee turnover & & 0.971 & & & & & \\
\hline L11: Motivation plan & & 0.769 & & & & & \\
\hline L12: Employee training program & & 0.866 & & & & & \\
\hline
\end{tabular}


Table 4 continued

\begin{tabular}{|c|c|c|c|c|c|c|}
\hline Measurement items & Factor 1 Factor 2 & Factor 3 & Factor 4 & $\begin{array}{l}\text { Eigen } \\
\text { value }\end{array}$ & $\begin{array}{l}\text { Cum. \% variance } \\
\text { explained }\end{array}$ & $\begin{array}{l}\text { Cronbach's } \\
\text { alpha }\end{array}$ \\
\hline B1: Buyer-supplier partnership level & & 0.784 & & 17.741 & 76.815 & 0.985 \\
\hline B2: Information share & & 0.892 & & & & \\
\hline B3: Group participation & & 0.782 & & & & \\
\hline B4: Expansion capability & & 0.990 & & & & \\
\hline B5: Planning and ERP execution systems & & 0.628 & & & & \\
\hline B6: Supplier collaborative planning systems & & 0.892 & & & & \\
\hline B7: Raw material and resource usage rate & & 0.910 & & & & \\
\hline B8: Internal process efficiency & & 0.902 & & & & \\
\hline B9: Percentage of wrong products during production & & 0.428 & & & & \\
\hline B10: Supplier rejection rate & & 0.991 & & & & \\
\hline B11: Total supply chain cycle time & & 0.730 & & & & \\
\hline B12: Supplier lead time against industry norms & & 0.729 & & & & \\
\hline B13: Level of supplier's defect free deliveries & & 0.986 & & & & \\
\hline B14: Purchase order cycle time & & 0.781 & & & & \\
\hline B15: Planned process cycle time & & 0.908 & & & & \\
\hline B16: Effectiveness of master production schedule & & 0.679 & & & & \\
\hline B17: Capacity utilization & & 0.679 & & & & \\
\hline B18: Efficiency of purchase order cycle time & & 0.921 & & & & \\
\hline B19: Frequency of delivery & & 0.981 & & & & \\
\hline $\mathrm{C} 1$ : Customer query time & & & 0.746 & 12.184 & 91.857 & 0.911 \\
\hline C2: Level of customer perceived value of product & & & 0.820 & & & \\
\hline C3: Range of products and services & & & 0.948 & & & \\
\hline C4: Order lead time & & & 0.819 & & & \\
\hline C5: Flexibility of service system to meet particular customer needs & & & 0.938 & & & \\
\hline C6: Delivery lead time & & & 0.619 & & & \\
\hline C7: Percentage of on-time deliveries & & & 0.906 & & & \\
\hline C8: Effectiveness of delivery invoice methods & & & 0.811 & & & \\
\hline C9: Client retaining & & & 0.928 & & & \\
\hline C10: Accuracy of forecasting techniques & & & 0.614 & & & \\
\hline C11: Market share & & & 0.938 & & & \\
\hline C12: Answer time of complaint & & & 0.829 & & & \\
\hline C13: After-sale service quality level & & & 0.918 & & & \\
\hline C14: Price & & & 0.619 & & & \\
\hline C15: Rate of credit & & & 0.946 & & & \\
\hline C16: Wasting degree of energy sourcing & & & 0.820 & & & \\
\hline C17: Number of distribution channels & & & 0.668 & & & \\
\hline C18: Time required to produce new product & & & 0.748 & & & \\
\hline C19: Average units returned & & & 0.939 & & & \\
\hline C20: Environment protection efficiency & & & 0.819 & & & \\
\hline C21: Production flexibility & & & 0.948 & & & \\
\hline C22: Delivery reliability & & & 0.619 & & & \\
\hline C23: Responsiveness to urgent deliveries & & & 0.921 & & & \\
\hline C24: Effectiveness of distribution planning schedule & & & 0.843 & & & \\
\hline C25: Quality of delivery documentation & & & 0.819 & & & \\
\hline C26: Driver reliability for performance & & & 0.941 & & & \\
\hline C27: Quality of delivered goods & & & 0.948 & & & \\
\hline C28: Achievement of defect free deliveries & & & 0.819 & & & \\
\hline
\end{tabular}


Table 5 Correlations results

\begin{tabular}{|c|c|c|c|c|c|}
\hline & & Finance & Customer & Learning & Business \\
\hline \multirow[t]{3}{*}{ Finance } & Pearson correlation & 1 & $0.809^{\mathrm{a}}$ & $0.757^{\mathrm{a}}$ & $0.866^{\mathrm{a}}$ \\
\hline & Sig. (2-tailed) & & 0 & 0 & 0 \\
\hline & $N$ & 301 & 301 & 301 & 301 \\
\hline \multirow[t]{3}{*}{ Customer } & Pearson correlation & $0.809^{\mathrm{a}}$ & 1 & $0.743^{\mathrm{a}}$ & $0.791^{\mathrm{a}}$ \\
\hline & Sig. (2-tailed) & 0 & & 0.013 & 0 \\
\hline & $N$ & 301 & 301 & 301 & 301 \\
\hline \multirow[t]{3}{*}{ Learning } & Pearson correlation & $0.757^{\mathrm{a}}$ & $0.743^{\mathrm{a}}$ & 1 & $0.791^{\mathrm{a}}$ \\
\hline & Sig. (2-tailed) & 0 & 0.013 & & 0.114 \\
\hline & $N$ & 301 & 301 & 301 & 301 \\
\hline \multirow[t]{3}{*}{ Business } & Pearson correlation & $0.866^{\mathrm{a}}$ & $0.791^{\mathrm{a}}$ & $0.791^{\mathrm{a}}$ & 1 \\
\hline & Sig. (2-tailed) & 0 & 0 & 0.114 & \\
\hline & $N$ & 301 & 301 & 301 & 301 \\
\hline
\end{tabular}

${ }^{a}$ Correlation is significant at the 0.01 level (2-tailed)

Fig. 1 BSC perspective correlation

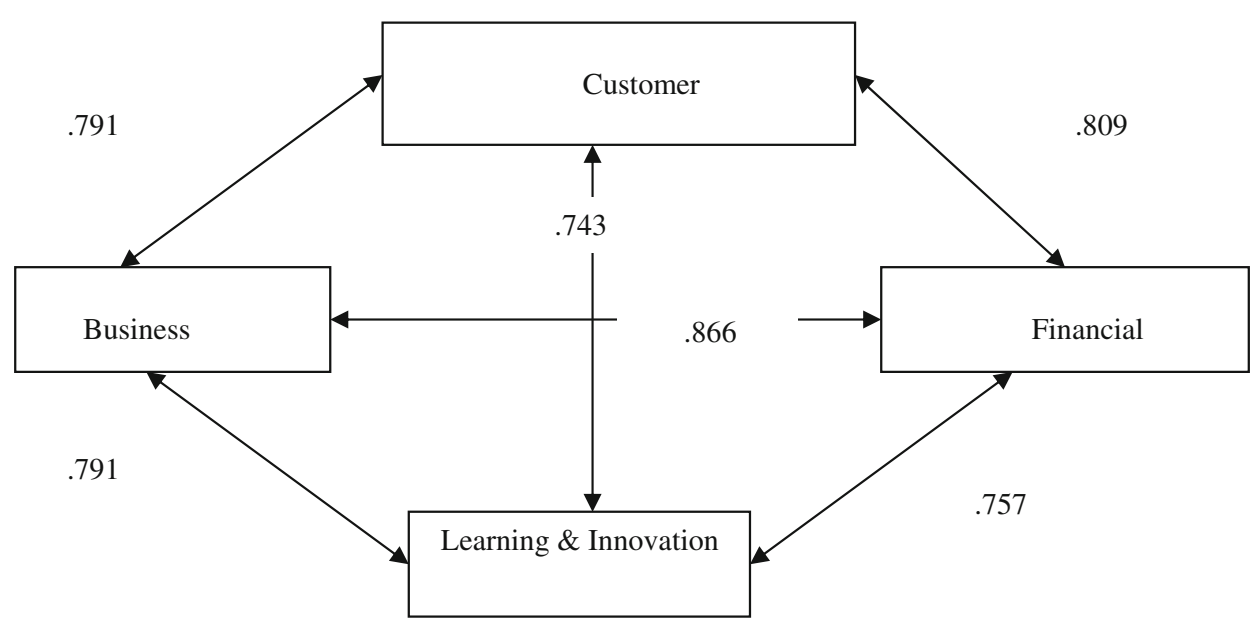

\section{Discussion}

Continuous improvement has to be applied across the supply chain. Most of companies use lean enterprise, six sigma and other productivity improvement techniques for continuous improvement (Huehn-Brown and Murray 2010). The proposed developed approach helps managers to apply such techniques more effectively by introducing effective metrics. Supply chain management should be more noted by engineering managers, due to the fact that value creation through supply chain activities plays an important role in the competitive market. In contrast to the traditional supply chain management, nowadays there is a fierce competition among supply chains rather than among firms. In addition, it should be noted that satisfaction of all categories of stakeholders leads to the total value of supply chain.
There are many supply chain performance metrics in the literature that some of them focused on value creation. It is difficult to monitor all the supply chain performance metric for managers in supply chain. It is necessary to identify actual value metric for all supply chain stakeholders and define correlation between them. There is a lack of definition for supply chain value metrics to create value for all stakeholders. Managers usually continue to pursue supply chain metrics as a means to increase value without attention on what really mean value in supply chain. We defined actual supply chain value metrics according to proposed framework. According to the results, engineering managers can identify the most important metrics and their effects on other BSC perspectives for applying lean manufacturing, line balancing, and dynamic facilities layout approaches to improve supply chain performance. High quality, low price, product development and, etc., are the competitive 
metrics in turbulent market place to survive, therefore business practices are essential fields for engineering function. Applying a proposed framework can guide engineering managers to redesign supply chain process according to value metrics. The reminder of this research is that the value concept has to be established between engineering managers as a practicing issue and applying for supply chain process design.

\section{Conclusion}

Creating more value via business and manufacturing process is a competitive advantage for engineering managers in today's market. There are many metrics, suggested in the past literatures, to evaluate supply chain performance. Evaluating all these metrics is difficult for engineering managers and they miss the monitoring of effective metrics as they are engaged with all metrics. Some of metrics proposed in the literature were fitted into more than one perspective of BSC. Some of them contradict other metrics and some of them may compromise others. This study proposes the use of a developed BSC framework using effective metrics to align companies' strategies and supply chain performance for creating more value.

Identifying key value metrics and defining their effects on other metrics can help engineering managers to improve the most important metrics instead of monitoring all of them. The proposed framework provides comprehensive metrics to evaluate supply chain performance with a focus on creating more value. The proposed metrics are concluded by reviewing literatures and they are selected with respect to interviews with experts in home appliance manufacturing industries. During interviews some new useful metrics were also identified. These metrics co-help managers to evaluate supply chain performance with respect to create more value for stakeholders such as employees who affect on total value creation in supply chain. This paper proves that every metric is more correlated with one of the perspective in BSC approach. Applying a quantitative method, the metrics are categorized into four main BSC perspectives. Survey research and factor analysis method were applied to identify the correlation between each metric and BSC perspective. The main objective of using factor analysis is to confirm effective selection of metrics for evaluating supply chain performance as it creates more value. Other studies in the past used qualified approaches to categorize metrics.

According to the past literatures, there is a cause-andeffect relationship between perspectives of the BSC and some studies tried to prove these relationships. This paper identifies the intensity of correlation between perspectives of BSC using a statistical method based on a real case study in home appliance manufacturing industries. Therefore, correlations between the perspectives of BSC were identified. Using the proposed framework, managers can improve their supply chain performance in a balanced way. This proposed framework would help managers of supply chains to better grasp the main facets of supply chain performance evaluation and aids them to take the right actions to enhance the overall performance and to speed up supply chain improvements. Developing a dynamic model based on knowledge management, performance metrics can be generated in the proposed framework. Generating metrics, continuous evaluation and result analysis are the most essential keys to the successful implementation of proposed framework using accurate information and information sharing in supply chain management.

Open Access This article is distributed under the terms of the Creative Commons Attribution License which permits any use, distribution, and reproduction in any medium, provided the original author(s) and the source are credited. 


\section{Questionnaire}

SECTION A: GENERAL ORGANISATIONAL INFORMATION

A1. Name of your company:

A2. Age:

A3. Your current position:

A4. Education:

A5: Number of years you have been in service:

\section{SECTION B: ASSESSMENT OF COMPANY'S CURRENT PERFORMANCE}

There are different metrics for each of the five scales on this section. In your opinion, tick on a level of each continuum that represents your assessment regarding the metrics about your company's performance.

\section{"How do you assessment your company's performance regarding each of these metrics?"}

\begin{tabular}{|c|c|c|c|c|c|}
\hline Measurement Items & $\begin{array}{l}\text { Strongly } \\
\text { good }\end{array}$ & good & middle & bad & $\begin{array}{l}\text { Strongly } \\
\text { bad }\end{array}$ \\
\hline \multicolumn{6}{|l|}{ Cash to cash cycle time } \\
\hline \multicolumn{6}{|l|}{ Financial benefits } \\
\hline \multicolumn{6}{|l|}{ Final net profit } \\
\hline \multicolumn{6}{|l|}{ Value of stock } \\
\hline \multicolumn{6}{|l|}{$\begin{array}{l}\text { Sale rate new product sale } \\
\text { ratio }\end{array}$} \\
\hline \multicolumn{6}{|l|}{ Reverse logistics costs } \\
\hline \multicolumn{6}{|l|}{ Logistics cost } \\
\hline \multicolumn{6}{|l|}{ productivity on time } \\
\hline \multicolumn{6}{|l|}{ waste reduction } \\
\hline \multicolumn{6}{|l|}{ security costs } \\
\hline \multicolumn{6}{|l|}{ cost of manpower resources } \\
\hline \multicolumn{6}{|l|}{ Purchase costs } \\
\hline \multicolumn{6}{|l|}{ Rate of return on investment } \\
\hline \multicolumn{6}{|l|}{ Variations against budget } \\
\hline \multicolumn{6}{|l|}{$\begin{array}{lll}\begin{array}{l}\text { Supplier } \\
\text { initiatives }\end{array} & \text { cost } & \text { saving } \\
\end{array}$} \\
\hline \multicolumn{6}{|l|}{ Cost per operation hour } \\
\hline \multicolumn{6}{|l|}{$\begin{array}{l}\text { Total inventory cost as: } \\
\text { Incoming stock level }\end{array}$} \\
\hline \multicolumn{6}{|l|}{$\begin{array}{l}\text { Total inventory cost as: } \\
\text { Work-in-progress }\end{array}$} \\
\hline \multicolumn{6}{|l|}{$\begin{array}{l}\text { Total inventory cost as: } \\
\text { Scrap value }\end{array}$} \\
\hline \multicolumn{6}{|l|}{$\begin{array}{l}\text { Total inventory cost as: } \\
\text { Finished goods in transit }\end{array}$} \\
\hline \multicolumn{6}{|l|}{ Cost reduction project } \\
\hline \multicolumn{6}{|l|}{ Information carrying cost } \\
\hline \multicolumn{6}{|l|}{ learning abilities } \\
\hline \multicolumn{6}{|l|}{ innovation abilities } \\
\hline \multicolumn{6}{|l|}{ product recycle interest } \\
\hline \multicolumn{6}{|l|}{ Use of new technology } \\
\hline \multicolumn{6}{|l|}{$\begin{array}{l}\text { Supplier assistance in solving } \\
\text { technical problems }\end{array}$} \\
\hline \multicolumn{6}{|l|}{$\begin{array}{l}\text { Supplier ability to respond to } \\
\text { quality problems }\end{array}$} \\
\hline $\begin{array}{lll}\begin{array}{l}\text { Supplier's booking } \\
\text { procedures }\end{array} & \text { in } \\
\end{array}$ & & & & & \\
\hline
\end{tabular}




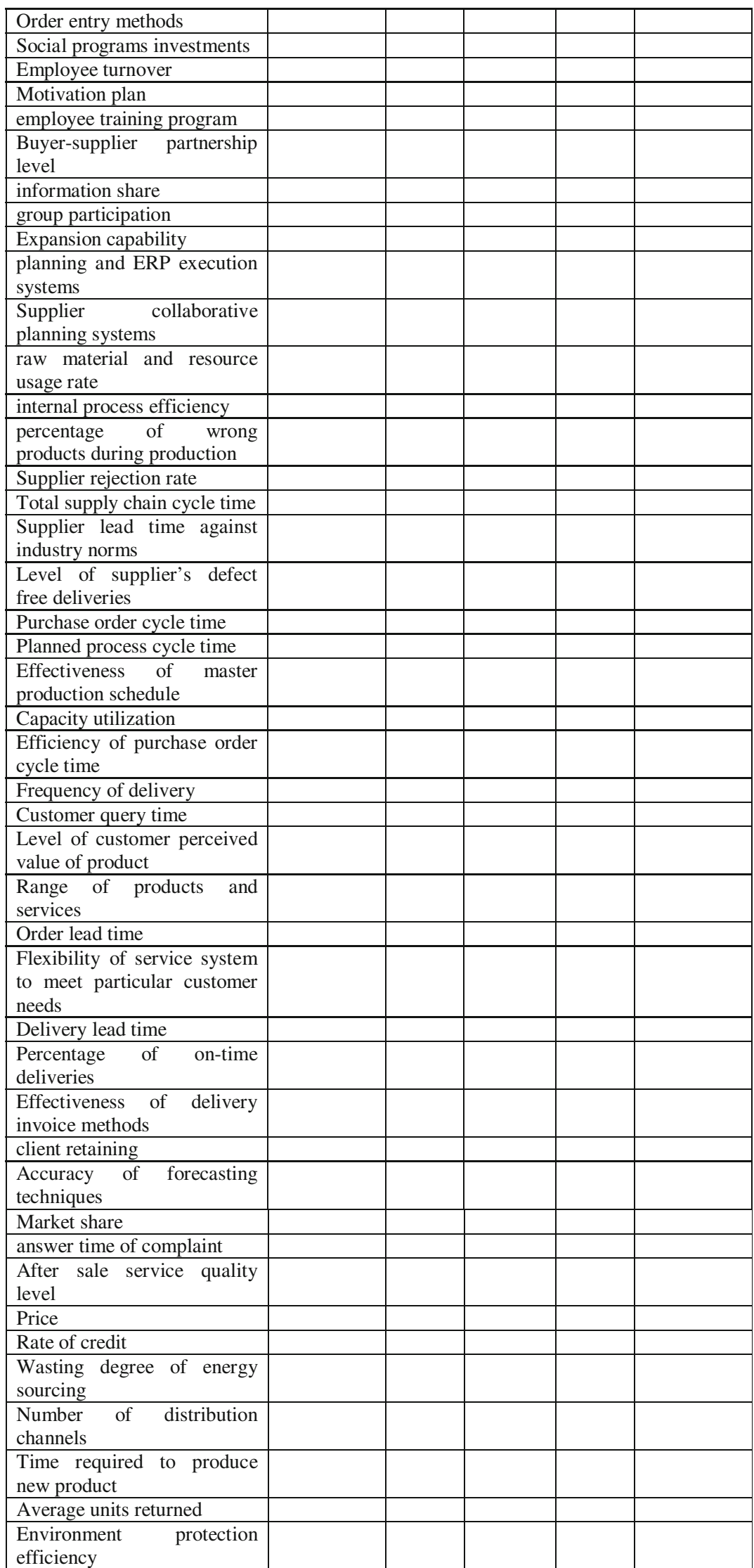




\begin{tabular}{|l|l|l|l|l|l|}
\hline Production flexibility & & & & & \\
\hline Delivery reliability to urgent & & & & & \\
\hline $\begin{array}{l}\text { Responsiveness } \\
\text { deliveries }\end{array}$ & & & & \\
\hline $\begin{array}{l}\text { Effectiveness of distribution } \\
\text { planning schedule }\end{array}$ & & & & & \\
\hline $\begin{array}{l}\text { Quality of delivery } \\
\text { documentation }\end{array}$ & & & & & \\
\hline $\begin{array}{l}\text { Driver reliability for } \\
\text { performance }\end{array}$ & & & & & \\
\hline Quality of delivered goods & & & & \\
\hline $\begin{array}{l}\text { Achievement of defect free } \\
\text { deliveries }\end{array}$ & & & & \\
\hline
\end{tabular}

\section{References}

Angerhofer BJ, Angelides MC (2006) A model and a performance measurement system for collaborative supply chains. Decis Support Syst 42(1):283-301

Arksey H, Knight P (1999) Interviewing for social scientists: an introductory resource with examples. Sage Publications, London

Bahri M, Tarokh MJ (2012) A seller-buyer supply chain model with exponential distribution lead time. J Ind Eng Int 8:13

Beamon BM (1999) Measuring supply chain performance. Int J Oper Prod Manag 19(3):275-292

Bhagwat R, Sharma MK (2007) Performance measurement of supply chain management: a balanced scorecard approach. Comput Ind Eng 53(1):43-62

Bititici US, Cavalieri S, Cieminski G (2005) Implementation of performance measurement systems: private and public sectors. Editor Prod Plan Control 16(2):99-100

Bolstorff P (2003) Measuring the impact of supply chain performance. CLO Chief Logist Off 12:5-11

Butler Renee J, Ammons Jane C, Joel Sokol (2006) Planning the supply chain network for new products: a case study. Eng Manag J 18(1):35-43

Cai J, Liu X, Xiao Z, Liu J (2009) Improving supply chain performance management: a systematic approach to analyzing iterative KPI accomplishment. Decis Support Syst 46:512-521

Camerinelli E, Cantu A (2006) Measuring the value of supply chain. Supply Chain Pract 8(2):40-59

Chan FTS (2003) Performance measurement in a supply chain. Int J Adv Manuf Technol 21(7):534-548

Chan FTS, Qi HJ (2003a) An innovative performance measurement method for supply chain management. Supply Chain Manag Int J 8(3):209-223

Chan FTS, Qi HJ (2003b) Feasibility of performance measurement system for supply chain: a process-based approach and measures. Integr Manuf Syst 14(3):179-190

Chan FTS, Chan HK, Qi HJ (2006) A review of performance measurement systems for supply chain management. Int $\mathbf{J}$ Bus Perform Manag 8(2/3):110-131

Chopra S, Meindl P (2001) Supply chain management: strategy, planning, and operation. Prentice Hall, New Jersey

Christopher M (1992) Logistics and supply chain management. Pitman Publishing, London

De Vaus D (2002) Surveys in Social Research. 5th edition, Routledge

Dobler DW, Burt DN (1996) Purchasing and Supply Management. The McGraw-Hill Companies, New York

Donnet ML, Weatherspoon DD, Charles BM (2009) Measuring food product differentiation by quality ratings: a cross-entropy analysis of specialty coffee e-auctions. J Agric Econ 61(1):122-137
Estampe D, Lamouri S, Paris JL, Brahim-Djelloul S (2010) A framework for analysing supply chain performance evaluation models. Int J Prod Econ 128(1), (in press)

Gunasekaran A, Patel C, Tirtiroglu E (2001) Performance measures and Metrics in a supply chain environment. Int J Prod Oper Manag 21(1/2):71-87

Gunasekaran A, Patel C, McGaughey RE (2004) A framework for supply chain performance measurement". Int J Prod Econ 87(3):333-347

Hongxia J, Zhipeng C (2007) Performance Appraisal on Supply Chain Based on Value Engineering and Multistage Fuzzy Comprehensive Evaluation. In: Proceeding of International conference in Wireless Communications, Networking and Mobile, Shanghai, pp 21-25

Hudson M, Lean J, Smart PA (2001) Improving control through effective performance measurement in SMEs. Prod Plan Control 12(8):804-813

Huehn-Brown WL, Murray S (2010) Are companies continuously improving the supply chain? Eng Manag J 22(4):3-10

Kaplan R, Norton D (1992) The balanced scorecard: measures that drive performance. Harv Bus Rev 70(1):71-99

Khalifa AS (2004) Customer value: a review of recent literature and an integrative configuration. J Manag Decis 42(5):645-666

Kleijnen JPC, Smits-Pefformance MT (2003) Performance metrics in supply chain management. Oper Res Soc Ltd 54(1):507-514

Lee HL, Billington C (1992) Managing supply chain inventory: Pitfalls and opportunities. Sloan Manag Rev 1:65-73

Levy DL (1997) Lean production in an international supply chain. Sloan Manag Rev 38(2):94-102

Li X, Jian GuX, Gang Liu Z (2009) A strategic performance measurement system for firms across supply and demand chains on the analogy of ecological succession. $J$ Ecol Econ 68(12):2918-2929

Liberatore MJ, Miller T (1998) A framework for integrating activitybased costing and the balanced scorecard into the logistics strategy development and monitoring process. J Bus Logist 19(2):131-154

Lockamy A III, McCormack K (2004) Linking SCOR planning practices to supply chain performance: an exploratory study. Int J Oper Prod Manag 24(11/12):1192-1218

Malmi T (2001) Balanced scorecards in Finnish companies: a research note. Manag Account Res 12(1):207-220

Martinsons M, Davison R, Tse D (1999) The balanced scorecard: a foundation for the strategic management of information systems. Decis Support Syst 25(1):71-88

Mason-Jones R, Towill DR (1997) Enlightening supplies. Manuf Eng 76(4):156-160

Mondragon AEC, Lalwani C, Mondragon CEC (2011) Measures for auditing performance and integration in closed-loop supply chains. J Supply Chain Manag 16(1):43-56 
Neely A (2005) The evolution of performance measurement research: developments in the last decade and a research agenda for the next". Int J Oper Prod Manag 25(12):1264-1277

Norrekilt H (2000) The balance on the balanced scorecard—a critical analysis of some of its assumptions. Manag Account Res 11(1):65-68

Rushton A, Oxley J (1991) Handbook of logistics and distribution management. Kogan Page, London

Sage Gordon W, Langmaid R (1998) Qualitative marketer research. Gower, Aldershot

Satapathy S, Mishra P (2013) A customer oriented systematic framework to extract business strategy in Indian electricity services. J Ind Eng Int 9:33

Sharma MK, Bhagwat R, Dangayach GS (2005) Practice of performance measurement: experience from Indian SMEs. Int J Glob Small Bus 1(2):183-213

Shepherd C, Günter H (2006) Measuring supply chain performance: current research and future directions. Int J Prod Perform Manag $55(3 / 4): 242-258$

Soni G, Kodali R (2010) Internal benchmarking for assessment of supply chain performance. Int J Benchmarking 17(1):44-76
Stewart GB (1991) The quest for value: a gide for senior managers. Harper Business, New York

Stewart G (1995) Supply chain performance benchmarking study reveals keys to supply chain excellence. Logist Inf Manag $8(2): 38-44$

Taghizadeh H, Hafezi E (2012) The investigation of supply chain's reliability measure: a case study. J Ind Eng Int 8:22

Toni AD, Nissimbeni G, Tonchia S (1994) New trends in supply environment. Logist Inf Manag 7(4):41-50

Wang C-H, Lu I-Y, Chen Chin B (2010) Integrating hierarchical balanced scorecard with non-additive fuzzy integral for evaluating high technology firm performance. Int J Prod Econ 128(1):413-426

Yang J (2008) Integrative performance evaluation for supply chain system based on logarithm triangular fuzzy number-AHP method. Emerald Group Publ Ltd Kybern 38(10):1760-1770

Yilmaz Y, Bititci U (2006) Performance measurement in the value chain: manufacturing vs. Tourism. Int J Prod Perform Manag 55(5):371-389

Youngblood Alisha D, Terry R (2003) Addressing balanced scorecard trade-off issues between performance metrics using multiattribute utility theory. Eng Manag J 15(1):11-17 